\title{
H)
}

Volume 17 Issue 4 Year: 2020

\section{A general assessment on alcohol use and smoking within the framework of Child Protection in Sport Programmes}

\author{
Aylin Uğurlu ${ }^{1}$ \\ Mustafa Yaşar Şahin ${ }^{2}$
}

\begin{abstract}
The purpose of this study is to provide an analysis of policies regarding alcohol use and smoking within the scope of Child Protection in Sport Programmes. Documents of international and national sports organisations have been reviewed using a document analysis technique. Findings of the research have been used in the study by way of a content analysis method. National and international sports organisations have set up various alcohol and cigarette policies with the intention of preventing child abuse in sports environments by being a role model to children, encouraging children not to acquire bad habits and thereby creating a healthier society. Consequently, policies regarding alcohol use and smoking will be recommended as part of the child protection scheme within the sports system in Turkey.
\end{abstract}

Keywords: Sport; child protection in sports; child abuse; child protection policy.

\section{Introduction}

The future of our societies depends on the mental protection and the physical, spiritual and moral development of our children. Sports activities have become an important part of modern community life and help support the development of children within different fields. The primary goal of parents and coaches is to help children find the success in sport they need to make them feel valued and wanted. (Parasiz et al, 2015)

In addition, sports are of vital importance for children and youth in their development as healthy individuals, both physically and mentally, who are free from bad habits. However, it also provides a basis for possible abuse (Yetim, 2011). Sports is highly regarded as an important communication medium, enabling individuals to establish efficient relationships (Kaplan and Cetinkaya, 2014). It is also an important interactive tool in the sense that it helps children to form new habits and behavioural patterns. Therefore, because many athletes mimic the behaviour and habits of their trainers, and see them as role models for their futures, the trainers should lead the children by example.

In accordance with the United Nations Convention on the Rights of the Child (UNCRC), 'child' is defined in all legal practices as a person under the age of eighteen (UNICEF, 2004). Accordingly, 'child' is defined in the legal regulations of Turkey as "any person who did not turn eighteen even if they reach puberty at an earlier age" (Kurt, 2015). Therefore, within both public and

\footnotetext{
1 Ph.D. Student, Gazi University, Department of Physical Education and Sport, ugurlu.aylin@gmail.com (iD) Orcid ID: 0000-0002-5148-7061

${ }^{2}$ Assoc. Prof. Dr., Gazi University, Faculty of Sports Sciences, mysahin@gmail.com ID Orcid ID: 0000-0002-4194-2358
} 
Uğurlu, A., \& Șahin, M. Y. (2020). A general assessment on alcohol use and smoking within the framework of child protection in sport programme. Journal of Human Sciences, 17(4), 986-998. doi:10.14687/jhs.v17i4.6068

private non-governmental organisations, all regulations and sanctions concerning children include all individuals who did not yet turn eighteen years of age. In this respect, regulations are made within the child protection sports system in order to prevent the negative behaviours and attitudes of trainers from leading the children into these same bad habits.

One of the principal regulatory issues is regarding the policies around alcohol use and smoking. The primary objective of the Child Protection System (CPS) is to take measures against the ill-treatment of children. Hence, keeping the children away from bad influences should help with their development into physically, mentally and psychologically healthy individuals.

Safeguarding within child and youth-serving organizations can include various policies, procedures, and practices that organizations can implement to prevent children from all kind of abuse. In order to create safer sports environments, child protection programmes preventing abuse and ill-treatment are being implemented all over the world (Çetin \& Hacisoftaoğlu, 2018).International organisations, such as the International Olympic Committee (IOC) and the United Nations International Children's Emergency Fund (UNICEF), have reported that children and young athletes face the risk of abuse and harassment in sporting areas and, therefore, official sanctions and policies should be imposed in order to protect them (Lang \& Hartill, 2015).Within the European regional alcohol policy of the World Health Organisation (WHO) (as suggested in Copenhagen in 2006), it is stated that, while sports and free time play an important role in the life of youth, alcohol use in sporting environments poses a threat for young people. Serious measures have been seen to be taken by the states in order to create healthier communities and ensure the well-being of children in all areas (WHO Regional Office for Europe, 2006; Aydemir, 2017; Aksakoğlu, 2003 \& Altay, 2007). In this respect, smoking, alcohol and substance use are defined as some of the most important public health concerns and measures are being taken to protect all individuals, and particularly the children, in Turkey as well as in other countries. In sporting environments, particularly where children socialize, numerous policies are being implemented to improve health and protection.

Generally, when we speak of abuse, the public is mostly focused on sexual abuse because of the great indignation that it raises. However, other types of abuse are more frequent within sporting and other fields (Brackenridge \& Rhind, 2014). Indeed, many studies have revealed that alcohol use is a triggering factor in many sexual abuse cases. Brackenridge and Kirby (1997) conducted a study on the abuse of athletes and concluded that abuse generally takes place in locker rooms, on the fields, during stop-overs when travelling, in the car or home of the trainer and particularly in social situations where alcohol is used. Historically it has been seen that some sport organisations in Europe initiated studies on child protection in sport in the late 1990s and implemented policies and procedures. Practices initiated by various sports associations in United Kingdom, Canada and Australia (the pioneers of Child Protection in Sports Programmes), have been put into practice by international sports institutions, national sports federations and sports clubs, and other sports organisations through regulations within the pyramid structuring (Fasting, 2005; UNICEF, 2010; Parasiz et al, 2015). These procedures can be summarised into three main categories; all kinds of banned substances such as alcohol, drugs and cigarettes during competitions, travels and camps should not be used; trainers and other officials in charge of the club and the team should not be under the influence of alcohol; and cigarettes and alcohol should not be available in places where athletes are present. The underlying factor for taking these measures is the regard for general health and protection of children (UNICEF, 2004).

Consequently, sporting organisations have taken binding decisions on child protection in sports programmes specifically around alcohol use and smoking. In consideration of the adverse effects of alcohol use and smoking on the health of children, it is important to review the measures taken against alcohol and cigarettes and their implementation. From this point forth, the purpose of the research is determined as the "review of alcohol use and smoking within the scope of child protection in the sports system". It is hoped that this research will contribute to the field and help future researchers as currently there are only a few studies on the subject in national and international literature. 
Uğurlu, A., \& Șahin, M. Y. (2020). A general assessment on alcohol use and smoking within the framework of child protection in sport programme. Journal of Human Sciences, 17(4), 986-998. doi:10.14687/jhs.v17i4.6068

\subsection{Literature review}

\subsubsection{Policies Regarding Alcohol Use and Smoking in General Child Protection System}

Within Turkey, the Ministry of Family and Social Policies is the main institution responsible for implementing public policies within the child protection system (Salim, 2011). The Child Protection Act No.5295 dated 2005 (CPA) adopts the principle of attaching priority to the interests of children in all transactions regarding the children (Demiral, 2018). In addition, in the National Strategy Paper and Action Plan on the Rights of the Child, the Ministry of Youth and Sports, Ministry of National Education, Ministry of Health, Ministry of Labour and Social Security and other institutions are designated as institutions responsible for implementing the necessary injunctions for the protection of the child (Supporting Fundamental Rights Reforms in Turkey, 2017).

As stated previously, studies on child neglect and abuse emphasise that alcohol use and smoking have adverse effects upon children. It is generally seen that abusers have drug and alcohol issues (Savaşç1, 2012) indicating that use of alcohol by the abuser is an important factor (Bulut, 2017). This situation is reflected in the legal measures that have been taken.

Children who are not protected against social dangers and alcohol or drug use by their parents are regarded as children in need of protection in the Law on Social Services and Child Protection Institution No.2828 (Elimination of child labour, protection of children and young persons, Act No. 2828 on social services and child protection agency, 1983-05-24, Article 3 / b, 2004). Furthermore, Article 58 of our Constitution titled "Protection of Youth" commissions the state to take necessary measures to protect young people from bad habits (drugs and alcohol) by exploiting the positive power of sports in order to raise a healthier young generation (Constitution of the Republic of Turkey, 1982).

Upon review of other relevant legal legislations, it is seen that the Spirits and Alcoholic Beverages Monopoly Act No.5130 bans the sale of alcoholic beverages in many educational institutions and sports facilities where there are children, and to everybody under the age of eighteen. The Primary Education Law states that shops that sell alcoholic beverages cannot be located within a certain distance of schools and that sufficient measures should be taken to protect children (National Programme On The Elimination Of Child Labour, 2017).

There are various action plans regarding smoking in Turkey, such as implementing legal regulations to prevent smoking in areas used for sports, playgrounds and walking trails. It is also suggested that activities should be organized in educational places like youth camps and centres with the support of role models (artists and athletes) for all children and young people at every level of education (WHO European Region 2018-2023, 2018).

When reviewing international regulations, it is seen that serious measures have been taken in Europe regarding the implementation of smoke-free zones. In Austria, for example, smoking is prohibited within a distance of ten meters around playgrounds. This distance is also compulsory around schools, sport centres and public parks. Similarly, smoking is prohibited in kindergartens, schools, student dormitories and areas where children work out (Council Recommendation of 30 November 2009 on Smoke-free Environments, 2009).

At the World Health Organisation Ministerial Conference on Young People and Alcohol in 2001 a Declaration on Young People and Alcohol (the Stockholm Declaration) was drawn up. European regional representatives came to an agreement on the achievement of ten targets. These targets included reducing substantially the number of young people who start consuming alcohol; reducing substantially the occurrence and frequency of high-risk drinking among young people, especially adolescents and young adults; providing and/or expanding meaningful alternatives to alcohol and drug use; increasing education and training for those who work with young people; and supporting actions against the illegal sale of alcohol (Oktuğ-Zengin, 2013). 
Uğurlu, A., \& Șahin, M. Y. (2020). A general assessment on alcohol use and smoking within the framework of child protection in sport programme. Journal of Human Sciences, 17(4), 986-998. doi:10.14687/jhs.v17i4.6068

The Declaration on Young People and Alcohol approves the following principles:

1. All people have the right to a family, community and working life protected from accidents, violence and other negative consequences of alcohol consumption.

2. All people have the right to valid impartial information and education, starting early in life, on the consequences of alcohol consumption on health, the family and society.

3. All children and adolescents have the right to grow up in an environment protected from the negative consequences of alcohol consumption and, to the extent possible, from the promotion of alcoholic beverages.

4. All people with hazardous or harmful alcohol consumption and members of their families have the right to accessible treatment and care.

5. All people who do not wish to consume alcohol, or who cannot do so for health or other reasons, have the right to be safeguarded from pressures to drink and be supported in their non-drinking behaviour (European Charter on Alcohol, 1995).

Protecting and promoting the health and well-being of children and young people is central to the United Nations Convention on the Rights of the Child. In addition, under the guidance of the World Health Organisation's (WHO) policies implemented in Europe with the slogan of "21 Targets in 21st Century", "The Health for All Target 21" has also been implemented in Turkey (Kumar \& Preetha, 2012). As a consequence of these policies, the Department of Sports Services has set a target for local administrations, non-governmental organisations, institutions and organisations to establish clubs where children and young people can work out, participate in cultural activities and not be exposed to cigarette smoke.

Violence in the field of sports can be expressed in many ways. One of them is alcohol use due to peer pressure. Alcohol is a serious risk factor in environments where children are engaged in sports. When alcohol in readily available in social spaces and schools where young people are present, bad treatment and dangerous acts are often observed (UNICEF, 2010).

\subsubsection{Alcohol Use and Smoking within the Scope of Child Protection Policies in Sports Organisations}

In general, child protection regulations are directly or indirectly of particular concern to the leading sporting organisations, particularly the International Olympic Committee (IOC) and the International Sports Federations (ISFs). International sports organisations are managed in line with the principle of monist representation of modern sports by the non-governmental, multi-national and multi-branch IOC established in accordance with the rules and principles of the law of nations and multi-national and single-branch ISF. Accordingly, decisions taken, and principles adopted by international sports organisations within the pyramid structuring are valid all around the world. This leadership role includes the child protection system in sports as well as in all events and situations involving sports. By reviewing the sanctions, principles and policies of the IOC in this regard, it can be seen that the emphasis is put on the influence of alcohol on harassment and abuse in sports.

The IOC explains this as follows; "Athletes are silenced by the sexual harassment and abuse process. The risk of sexual harassment and abuse is greater when there is a lack of protection, high perpetrator motivation and high athlete vulnerability (especially in relation to age and maturation). There is no evidence that the amount of clothing cover or the type of sport are risk factors: these are myths. Research identifies risk situations as the locker-room, the playing field, trips away, the coach's home or car, and social events, especially where alcohol is involved. Team initiations or end-of-season celebrations can also involve sexually abusive behaviour against individuals or groups" (IOC, 2007). 
Uğurlu, A., \& Șahin, M. Y. (2020). A general assessment on alcohol use and smoking within the framework of child protection in sport programme. Journal of Human Sciences, 17(4), 986-998. doi:10.14687/jhs.v17i4.6068

In a study by Mountjoy et al. (2018), this situation highlighted by the IOC is stated as follows: "The International Olympic Committee states that physical abuse occurs more frequently especially due to the use of alcohol. The study reveals that the athletes may be forced to consume alcohol and consequently they may harm each other due to acts of violence and they may go overboard in celebrations which would result in physical and sexual abuse." (Fasting, Brackenridge \& SundgotBorgen, 2004, Mountjoy et al. 2016).

The IOC have laid down organisational measures to protect the athletes and imposed some sanctions and bans regarding alcohol and cigarette in consideration of the harmful nature of smoking. In consequence, smoking is banned in the Olympic village (except for a few places) and the sale of alcohol is banned (Rio 2016 Village Policies, 2016). Dutch gymnast Yuri van Gelder was suspended from the Olympic village during the Rio 2016 Olympic games due to alcohol use and applicability of the sanctions was thus proven.

The IOC and many other institutions have also taken necessary protection and security measures. For example, the Norwegian Olympic Committee has stated in their protection from sexual abuse and harassment policy that some sports clubs and national sports federations have received written or unwritten ethical codes regarding alcohol use - managers and trainers should never consume alcohol together with the athletes during travels or in national organisations (Safeguarding Athletes from Harassment and Abuse in Sport IOC Toolkit for IFs and NOCs, 2010). The US Olympic Committee implemented a regulation to create safe sports fields in which it is stated that alcohol use and smoking are brought under control and the sale of alcohol prohibited to persons under eighteen. They also stated that nobody should be under the influence of alcohol on sports fields. In addition, not only trainers, managers and volunteers, but also their companions, shall not be under the influence of alcohol in this period (United States Olympic Committee Safe Sport Strategy, 2012). This principle is included under the title of ethical principles for trainers in the US as "restriction of smoking and alcohol use" (Dolaşır, 2005).

In light of international decisions taken to protect children and their rights, International Sports Federations have also taken measures regarding alcohol use and smoking and implemented various policies along with the measures taken by the IOC. The International Basketball Federation (FIBA), the Union of International Football Associations (FIFA), the International Tennis Federation (ITF) and national associations and clubs in various branches of sports are among them. When analysed in detail, it is seen that some sporting organisations make decisions independently from the parent association.

Measures taken regarding alcohol use and smoking in the Child Protection Policy of the Oceania Basketball Confederation state that alcohol shall not be consumed, and one shall not be under the influence of alcohol when around children and while working. Nobody should smoke near children in sporting environments and in places where they can be seen by children (FIBA Oceania Child Protection Policy, 2014). The Australian Basketball Federation, which is the authorised body in basketball in the country in affiliation with FIBA, stipulated that alcohol use and smoking are not proper in sports activities in terms of health. Trainers should be very careful before, during and after training, and while travelling, when alcohol use and smoking are banned (Basketball Australia Member Protection Policy, 2018).

Review of various implementations reveals that international associations work cooperatively when it comes to child protection in sport and the use of alcohol and cigarettes. For example, FIFA and UNICEF conducted a joint study and implemented child protection strategies during the World Cup in South Africa in 2010 and imposed bans to protect the children in sporting environments from the harms of alcohol (Palmer-Felgate et al, 2013).

The International Association of Athletics Federations (IAAF) stipulates, in their codes of behaviour, that smoking is completely banned during trainings, alcoholic beverages should never be consumed before trainings and that trainers' breaths should not reek of alcohol (IAAF Code of Ethics for Coaches, 1999). Pursuant to the codes of ethics of IAAF, the Australian Athletics Federation included this article in their own codes of ethics. 
Uğurlu, A., \& Șahin, M. Y. (2020). A general assessment on alcohol use and smoking within the framework of child protection in sport programme. Journal of Human Sciences, 17(4), 986-998. doi:10.14687/jhs.v17i4.6068

The World Rugby Union emphasised the ban of alcohol use and smoking in their rules for trainers who work with children and stated in their codes of ethics that smoking is banned around the athletes and near sports facilities (World Rugby Union Child Safeguarding Policy, 2013). It states that nobody should act violently due to alcohol use and lose control with children and using alcohol is banned around the children and before trainings. The Scottish Rugby Federation, which is a subassociation within the international organisation, has created a list of behaviours to prevent the risk factors of the clubs. They state that consuming alcohol and smoking around children is an intolerable behaviour and these prohibited substances shall not be used around children. All stakeholders are obliged to follow the rules, those who use alcohol and other substances will be regarded as serious criminals and prosecuted by the authorities. Accepting that alcohol is a substance that may lead to sexual abuse, measures are taken especially for stop-over activities (away competitions, camps, matches, etc.) (Rugby Football Union Safeguarding Policy Guidance \& Procedures, 2013).

Similarly, the Irish Athletics Federation (IAF) has taken serious measures for child protection. Those who are responsible for children must avoid alcohol use before training, during competitions and in places such as hotels and camps. Keeping alcoholic beverages, cigarettes and other illegal products is prohibited and it is emphasised that trainers should be role models. The IAF states that an alcohol-free environment should be created in celebrations to ensure the validity of this matter for adults and clubs. Those who are engaged in sports should not accept sponsorship offers of alcohol and cigarette companies for their organisations (Athletics Ireland Code of Ethics \& Good Practice for Children in Athletics, 2005). The Australian Football Federation stipulates that no employee, including the volunteers, shall use alcohol or smoke during sport activities where persons under eighteen are involved and smoking is allowed only in designated places (Football Federation Australia National Member Protection Policy, 2016).

It was stated by the British Orienteering Federation that alcohol use and smoking shall not be allowed in places visible to children in order for them to be excellent role models and that healthy living spaces should be provided for children (British Orienteering O-Safe - A Guide for Safeguarding Children \& Vulnerable Adults in Orienteering, 2007).

The German Association for Protection of Children formed a policy to ensure that children work out in safe environments and stated that it is banned for trainers and other employees to consume alcohol and smoke around children - trainers and supervisors in violation of this may be punished (Kinderschutz im Berliner Sport, 2013).Sports clubs have imposed various policies around smoking and alcohol in their child protection programmes. For example, Mitchelstown Tennis Club of Ireland took the decision that "It is forbidden to use alcohol and smoke or to be under the influence of these substances during team works or all other organisations; smoking, alcohol and substance use is prohibited inside the facility or other places where the club is represented". (Mitchelstown Tennis Club Child Protection Policy, 2018).

Likewise, various basketball clubs and associations support alcohol and tobacco bans in their child protection policies (Basketball Australia Member Protection Policy, 2018; McKinnon Basketball Association Child Safe Policy, 2017). A Canadian winter sports club for children, (XC Bragg Creek) and an American sports club for children (CVYAA), established codes of behaviour for athletes, trainers and parents and imposed restrictions on alcohol use and smoking so that unwanted events such as bullying, harassment and physical and emotional abuse would not take place. The clubs which imposed serious sanctions of trainers proclaimed that alcohol use is forbidden whilst working out and that athletes should not be encouraged to use alcohol during events or celebrations. In addition, CVYAA stipulates in their trainer agreements that they should not reek of alcohol, they should not be under the influence of alcohol and they should not smoke around the athletes (XC Bragg Creek Ski and Bike Society (XCBC) Athlete, Parent and Coach Code of Conduct, 2018; CVYAA Coaches Code of Conduct, 2018). 
Uğurlu, A., \& Șahin, M. Y. (2020). A general assessment on alcohol use and smoking within the framework of child protection in sport programme. Journal of Human Sciences, 17(4), 986-998. doi:10.14687/jhs.v17i4.6068

Similarly, a university sports club, DCU (Dublin City of University), stated their alcohol use and smoking policy in their child protection plan as follows: "Symptoms of physical abuse include providing alcohol to athletes and poisoning them. In addition, it was reported that the athletes are sexually abused after they are forced to drink alcohol. Desire of athletes over the age of 10 to drink alcohol is regarded as a symptom of emotional abuse." DCU Sport also states that trainers, volunteers and other employees must follow their codes of behaviour and that alcohol use and smoking should be avoided before and during the activity (Dublin City University Sport Child Protection and Safeguarding Policy, 2018).A popular English football club, Arsenal, banned trainers from alcohol use and smoking in the company of young athletes in order to be good role models for them (Arsenal Football Club Safeguarding Children and Young People Policy \& Procedures, 2013).

Kröske (2016) stated that in his study on German football clubs involving young people and children, athletes mostly drunk alcohol when they were with their peers as a means of acceptance by the team. In addition, it is reported that the consumption of alcohol and tobacco among young people has increased especially in handball and football clubs in Germany (Heim \& Brettschneider, 2002; Kröske, 2016).

When reviewing non-governmental organisations, UNICEF stated in its Child Protection in Football programme that alcohol and tobacco should not be consumed in the company of children in order to avoid child abuse and the trainers being out of countenance. It stated that children imitate the behaviours of adults and thus, trainers should be seen to be good role models (Busana, 2010).

When the measures taken by sports organisations affiliated to the state were reviewed, it was seen that the New Zealand Sport Union banned alcohol use and smoking in the company of athletes and stated that a healthy lifestyle should be encouraged (Sport New Zealand Safe Sport for Children, 2017). The state set up strict rules for sports clubs regarding alcohol use.

As a universal concept, policies regarding child protection in sports have been implemented in various sports organisations and associations, and measures have been taken regarding alcohol and tobacco use so that children can work out in a safer environment. Child Protection in Sport Unit (CPSU), which is established in affiliation with the NSPCC in England, established a child protection unit and included in their codes of behaviour that adults should not smoke in places visible to children and not use alcohol before and during activities (Brackenridge and Rhind, 2014). Some sanctions have been imposed on trainers in Turkey to restrict their alcohol use and smoking as they are influential on and responsible for the children in sporting environments. These sanctions are included in the ethical principles of sports clubs. Rules that trainers should be role models in relation to health are included in the instructions of only a few federations in Turkey:

"National Team trainers must be the right role model. Having a university education is an important factor in the presentation of the trainer. National Team trainers should set an example with their lifestyles, appearance and human relationships. They should not use harmful substances like tobacco etc. where the tournament is held and in the company of athletes. It is extremely important that they have respectful and constructive communication with other trainers, parents, press members and managers. " (Turkish Tennis Federation, Criteria for National Team Trainers, 2010). area."

The Turkish Chess Federation states the following under the title of "Ethics for Trainers":

"Any kind of tobacco or alcoholic beverage should not be used in competition or training

There are rules concerning not only the trainers but also the athletes to prevent the harm caused by alcohol use and smoking. Paragraph 12, Article 12 of the Turkish Badminton Federation directive is as follows: athletes shall not use alcohol, drugs, tobacco and all kinds of banned substances during competition, travel and in camps. Paragraph 36 of the same article states: the athletes, trainers and managers who travel abroad as members of national team shall not buy alcoholic beverages from duty free shops or abroad. Sanctions and rules to be applied in the case of non-compliance are specified in Article 13 of the directive. Accordingly; 
Uğurlu, A., \& Şahin, M. Y. (2020). A general assessment on alcohol use and smoking within the framework of child protection in sport programme. Journal of Human Sciences, 17(4), 986-998. doi:10.14687/jhs.v17i4.6068

1. Full or partial restriction of participation in national team programs.

2. Discharging from the camp and/or competition, provided that they cover all travel and other costs.

3. Suspending payment of prizes, session fees etc. made by the federation.

4. Any sanction may be imposed in accordance with the provisions of the Disciplinary Instruction of the Federation (Turkish Badminton Federation National Team Duties and Responsibilities Directive, 2016).

\section{Method}

A qualitative research approach, using a document analysis technique, has been employed in this research. Documents issued by international sports organisations (IOC and ISF), national federations, clubs and some public organisations responsible for sports have been reviewed and the findings analysed using a content analysis method. Within the quantitative research technique, document analysis is the method where the researcher interprets all documents that support the research and makes sense of the subject of the study (Bowen, 2009). According to Marshall and Rossman (1999), reviewing and analysing documents is an efficient method by which to reveal the values and beliefs of participants (Marshall and Rossman, 1999)

This study supports the child protection in sport programme established by the IOC and compulsorily implemented by its sub-organisations. It is also considered that it will shed light on new formations regarding alcohol use and smoking and the safety and health of children in sporting environments by using various sanctions.

\section{Discussion and Conclusions}

According to the results obtained in the study basic measures are forefronted such as not using alcohol in sports environments and when traveling with the team, not being under the influence of alcohol, not smoking in the company of children and in places where they can see. It is also found out that some regulations are made regarding smoking ban and not allowing sale of alcohol in sports campuses covering large spaces such as olympic villages other than limited number of specified places.

The principles and sanctions regarding alcohol use and smoking play an important part in the measures taken by non-governmental international sports organisations and inter-governmental international roof organisations to enable children to work out in a safe environment. hen these prominent themes are reviewed in detail, it is seen that they are suggested to prevent child abuse, provide role models to children, prevent children from having bad habits and create an environment for healthy living.

The most important measure regarding alcohol is the preventing of managers, trainers and officials/volunteers using alcohol in the company of athletes during travelling or sporting events. The most important reason for these measures is that the influence of alcohol forms a basis for abuse and harassment (Lang ve Hartill, 2015; Brackenridge, Palmer-Felgate ve diğ., 2013; IOC, 2007). UNICEF conducted related studies on the grounds that alcohol forms a basis for sexual abuse (UNICEF, 2010).

In review of the literature, it is seen in the research reports of Widom and Hiller-Sturmhöfel (2001) and the studies of Levy and Zhou, (2016) and Kingsland et al. (2013) that the rate of harassment caused by alcohol use in both sports and other fields is very high. Mountjoy et al. (2016) reveal in their study that the most important cause for harassment is alcohol use and Van de Mortel (2008) states that harassment mostly takes place in environments where alcohol is consumed.. Accordingly, it is seen that this measure taken with regard to alcohol use by adults is a protective measure taken to prevent child harassment and abuse (Mountjoy et al. 2016, Widom \& HillerSturmhöfel, 2001; Levy \& Zhou, 2016; Kingsland et al, 2013; Van de Mortel, 2008). Another reason for the measures taken with regard to alcohol use and smoking stems from the admiration of children for their trainers, looking up to them and seeing them as role models. 
Uğurlu, A., \& Șahin, M. Y. (2020). A general assessment on alcohol use and smoking within the framework of child protection in sport programme. Journal of Human Sciences, 17(4), 986-998. doi:10.14687/jhs.v17i4.6068

Consequently the decisions that ban alcohol use and smoking before and during trainings are taken by many sports organisations within the pyramid organisation from international roof organisations to sports clubs (XC Bragg Creek Ski and Bike Society (XCBC) Athlete, Parent and Coach Code of Conduct, 2018; IOC, 2007; Dublin City University Sport Child Protection and Safeguarding Policy, 2018).

Additionally, not reeking of alcohol and smoke is a rule established for trainers because they are generally taken as role models by athletes under eighteen (IAAF Code of Ethics for Coaches, 1999; CVYAA Coaches Code of Conduct, 2018).

It is a known fact that trainers have influence over, and are responsible for, children in sports fields. Relevant literature supports this finding. For example: O'Boyle and Dawson (1992) emphasise in their study on role model relationships that individuals are influenced by each other in social surroundings. Various sports organisations in Turkey (Turkish Tennis Federation, Turkish Badminton Federation) include ethical rules and principles for trainers and referees regarding alcohol use and smoking in their directives though they are minimal (Turkish Tennis Federation Central Referee Board Instruction, 2013), Turkish Badminton Federation National Team Duties and Responsibilities Directive, 2016). When it is considered that the characteristic properties of children are developed in sport fields with role model behaviours from those who work in sports environments, it can be said that these measures will have direct effects in the future and could contribute a great deal to public health.

Another conclusion of the study is the necessity of protecting children from picking up bad habits and thereby creating healthy future generations. It is seen that measures taken to prevent adults (trainers, parents, spectators, employees) smoking in sporting environments where children can see them is beneficial as smoking is regarded as a factor that adversely affects their health (Arsenal Football Club Safeguarding Children and Young People Policy \& Procedures, 2013; McKinnon Basketball Association Child Safe Policy, 2017; Mitchelstown Tennis Club Child Protection Policy, 2018; FIBA Oceania Child Protection Policy, 2014). While these measures covering private places like sports clubs are extended far and wide, in Turkey they are limited to public facilities regarded as smoke-free air zones.

There are references to missing points in relevant literature. For example, Kröske (2016) calls attention to the fact that there is no unit controlling alcohol use in sporting environments. Accordingly, it is obvious that additional measures have to be taken for specified principles to be pursued along with sanctions such as discharging the trainers or removing the athletes from the national team or their local teams.

Another factor revealed in the study is the public health theme. The measures taken in this respect range from general to special. The suggestion that the measures taken regarding health will protect the health of individuals and thereby healthy individuals will constitute a healthy community is being taken into consideration. Accordingly, child protection policies are determined on the basis of public health. For example, decisions to ban and restrict the use and sale of harmful substances in confined spaces like schools and specified open spaces, youth camps organized for recreation or sport activities, and youth centres are important to protect the health of children and young people. Accordingly, it is seen that the measures taken regarding alcohol use and smoking in child protection in sport policies of the IOC and ISF, their national representatives and affiliated sports clubs and public institutions responsible for sports administration, are generally aimed at protecting the public health and particularly at protecting the health of athletes and individuals. Competent persons in sports administration, such as federation presidents, have a great responsibility to implement these policies and observe their effects. In order to eliminate the sexual, emotional and physical harms caused by alcohol use by those who are below legal age, or by adults in their company, the authorized persons should have the necessary knowledge in this respect and keep track of the implemented studies (Brackenridge, 2001).The above measures regarding alcohol use and smoking are taken within the organisational hierarchy in a pyramid structure - this is a characteristic property of sporting organisations. Specified policies affect the federations and clubs in all countries with reference to the 
Uğurlu, A., \& Șahin, M. Y. (2020). A general assessment on alcohol use and smoking within the framework of child protection in sport programme. Journal of Human Sciences, 17(4), 986-998. doi:10.14687/jhs.v17i4.6068

principles established by IOC and ISF. Implementation of the alcohol-tobacco ban decision included in IAAF's child protection in sport system by Australian Athletic Federation and clubs may be given as an example.

Accordingly, it seems necessary for Turkish federations to take measures regarding alcohol and tobacco in accordance with the general policies of the state and the principles of the international sports organisations that they are affiliated with, to determine policies in this respect and implement them. Unfortunately, only a small number of federations such as the Turkish Chess Federation, Turkish Badminton Federation and Turkish Tennis Federation have made regulations regarding alcohol and tobacco, thereby enabling children to work out in safe environments.

Consequently, it is seen that there are special implementations in sports administrations regarding alcohol use and smoking to ensure sports are carried out in a safe environment. Such measures and implementations are not at the desired level yet in Turkey and this fact is thoughtprovoking. Therefore, it is necessary to make policies regarding alcohol and tobacco use in child protection in sport system in Turkey in order to protect child athletes from bad habits, sexual abuse and negligence and to thereby create a healthy community. The most important point in this respect is that the trainers should not use alcohol and tobacco as they are regarded as role models and/or use alcohol or smoke in places where they can be seen by children.

In consideration of this information, stakeholder organisations in sports administration should determine compulsory principles and procedures in order to prevent the problems arising from alcohol and tobacco use and implement common policies. From that point forth, it is recommended to establish policies regarding alcohol use and smoking as part of the child protection in sport system in Turkey.

\section{References}

Action plan to improve public health preparedness and response in the WHO European Region 2018-2023. (2018). Retrieved from: http://www.euro.who.int/ data/assets/pdf file/0009/393705/ActionPlan EN WHO web 2.pdf?ua=1

Aksakoğlu, G. (2003). Sovyetler Birliği özelinde sosyalist ülkelerde sağlik reform, Community and Physician. 18, 68-80.

Altay, A. (2007). Sağlık hizmetlerinin sunumunda yeni açılımlar ve Türkiye açısından değerlendirilmesi, Journel of Turkish Court of Account. 64, 33-58.

Arsenal Football Club Safeguarding Children and Young People Policy \& Procedures. (2013). Retrieved from: https://www.arsenal.com/sites/default/files/documents/affiliated footballs safeguard 0.pdf.

Aydemir, I. (2017). Health system financing objectives and policy instruments, Akademik Bakış Uluslararas1 Hakemli Sosyal Bilimler Dergisi, 62,410-428.

Basketball Australia Member Protection Policy. (2018). Retrieved from: https://australia.basketball/wp-content/uploads/2018/06/BA-Member-ProtectionPolicy-Revised-June-2018.pdf

Bowen G. A. (2009). Document analysis as a qualitative research method. Qualitative Research Journal, 9(2), 27-40.

Brackenridge, C. \& Kirby, S. (1997). Playing safe: assessing the risk of sexual abuse to elite child athletes. International Review for the Sociology of Sport, 32(4),407-418.

Brackenridge, C., \& Rhind, D. (2013). Researching and enhancing athlete welfare: proceedings of the 2nd international symposium of the brunel international research network for athlete welfare (BIRNAW). Uxbridge: Brunel University Press. Retrieved from: http://www.brunel.ac.uk/sse/sport-sciences/research/bcshaw/birnaw

Brackenridge, C. H \& Rhind, D. (2014). Child protection in sport: reflections on thirty years of science and activism. Social Science, 3(3), 326-340. doi:10.3390/socsci3030326. 
Uğurlu, A., \& Şahin, M. Y. (2020). A general assessment on alcohol use and smoking within the framework of child protection in sport programme. Journal of Human Sciences, 17(4), 986-998. doi:10.14687/jhs.v17i4.6068

Brackenridge, C. H. (2001). Spoilsports: Understanding and preventing sexual exploitation in sport. London: Routledge.

British Orienteering (2007). O-Safe. Retrieved from: https://www.britishorienteering.org.uk/images/uploaded/downloads/governance polici es osafe.pdf.

Bulut, S. (2017). The Problem of Defining Sexual Abuse in Children, Turkish Psychological Counseling and Guidance Journal, 28(3), 139-156.

Busana, M. (2010). Guidelines for Training of Trainers. UNICEF Education Kit Handbook. Retrieved https://www.unicef.org/supply/files/Education Kits User Manuals Module 1.pdf

Cetin, E. \& Hacisoftaoglu, I. (2018). A General evaluation of child abuse in sport, Batman University JournalofLifeSciences. 8, (2), 80-89.

Constitution of the Republic of Turkey.(1987). 7 November 1982, Article 58.59. Retrieved from: https://www.refworld.org/docid/3ae6b5be0.html.

Council recommendation of 30 November 2009 on smoke free environments. (2009/C 296/02). (2013). Official Journal of the EU, EC Brussels. Available from: https://eurlex.europa.eu/LexUriServ/LexUriServ.do?uri=OJ:C:2009:296:0004:0014:EN: $\underline{\mathrm{PDF}}$

CVYAA Coaches Code of Conduct. (2018). Retrieved from: https://static1.squarespace.com/static/576c5b95414fb5f6a4c4c1a2/t/5bfb3ce888251b85 d900fc5b/1543191784933/CVYAA+COACHES+CODE+OF+CONDUCT.pdf

Dublin City University Sport Child Protection and Safeguarding Policy.(2013). Retrieved from: https://www.dcu.ie/dcusport/child protection.shtml.

Demiral, E. (2018). Sexual abuse against children in the context of international human rights law, İstanbul, Unpublished Master dissertation, Beykent University Institute of social sciences, Istanbul.

Dolaşir, S. (2006). Antrenörlük Etiği ve İlkeleri, Gazi Kitapevi, Ankara.

Elimination of child labour, protection of children and young persons. (2004). Act No. 2828 on social services and child protection agency, 1983-05-24, Article 3 / b. Retrieved from:http://www.ilo.org/dyn/natlex/natlex4.detail?p_lang=en\&p_isn=70199\&p_countr $\mathrm{y}=$ TUR\&p_count $=781 \&$ p_classification $=04 \&$ p_classcount $=17$

European Charter on Alcohol adopted at the European Conference on Health (1995). Society and Alcohol, Paris, 12-14 December 1995. Retrieved from: http://www.euro.who.int/_data/assets/pdf_file/0008/79406/EUR_ICP_ALDT_94_0 3_CN01.pdf?ua $=1$

Fasting, K. (2005). Research on sexual harassment and abuse in sport. Institutt for Samfunnsfag Norges idrettshøgskole. Retrieved from: http://www.idrottsforum.org/articles/fasting/fasting050405.pdf

Fasting, K., Brackenridge, C.H, \& Sundgot-Borgen J. (2004). Prevalence of sexual harassment among Norwegian female elite athletes in relation to sport type. International Review for the Sociology of Sport. 39(4), 373-386.

FIBA Oceania Child Protection Policy. (2014); Retrieved from: https://websites.sportstg.com/get_file.cgi?id=3091976

Football Federation Australia National Member Protection Policy. (2016). Retrieved from:https://www.ffa.com.au/sites/ffa/files/2017-

09/National\%20Member\%20Protection\%20Policy.pdf

IAAF Code of Ethics for Coaches. (1999). Retrieved from: https://www.iaafethicsboard.org/Content/downloads/IAAF-Code-of-Ethics-eng.pdf.

Irish Athletics Federation Code of Ethics \& Good Practice for Children in Athletics. (2005). Retrieved from: https://www.athleticsireland.ie/downloads/other/code-of-ethics-forchildren soft.pdf. 
Uğurlu, A., \& Şahin, M. Y. (2020). A general assessment on alcohol use and smoking within the framework of child protection in sport programme. Journal of Human Sciences, 17(4), 986-998. doi:10.14687/jhs.v17i4.6068

International Olympic Committee (2007). Adopts consensus statement on "sexual harassment \& abuse in sport". 2007: Lausanne, 8 February. Retrieved from: https://stillmed.olympic.org/Documents/THE\%20IOC/OFFICIAL\%20SHA\%20State ment.pdf

International Olympic Committee, Olympic Charter (2007). Available from: https://stillmed.olympic.org/Documents/Olympic\%20Charter/Olympic_Charter_throu gh_time/2007-Olympic_Charter.pdf

Kaplan, Y., \& Cetinkaya, G. (2014) Socialization via sport- process of re-socialization, International Journal of Science Culture and Sport, 2,120-125.

Kinderschutz im Berliner Sport. (2013). Retrieved from: https://www.kinderschutz-im-sportberlin.de/wp-content/uploads/2016/12/handlungsleitfaden kinderschutz web.pdf

Kingsland, M., Wolfenden, L., \& Rowland, B.C. (2013). Alcohol consumption and sport: a crosssectional study of alcohol management practices associated with at-risk alcohol consumption at community football clubs. BMC Public Health, 13,762.

Kröske, B. (2016). Prediction model for alcohol consumption in young football players in German. Zeitschrift für Gesundheitspsychologie, 24(4)180-192.

Kumar, S. \& Preetha, G S. (2012). Health promotion: An effective tool for global health. Indian J Community Medican. 37(1):5-12.

Kurt, S.N.(2015). Basic international documents on children's rights and Turkey example. Journal of Social Policy Studies, 36, 99-127. doi:10.21560/spcd.28915.

Lang, M., Hartill, M. (2015). Safeguarding, Child Protection and Abuse in Sport: Int.Perspectives in Research, Policy and Practice.(Routledge Research in Sport, Culture and Society). London: Routledge.

Levy, A \& Zhou, J. (2016). Sports participation and alcohol use: associations with sports-related identities and well-being, Journal of studies on alcohol and drugs, 77:170-179.

Marshall, C.M \& Rossman G.B. (1999). Designing qualitative research, Thousand Oaks, Calif.: Sage Publications, Inc; 3th edition.

McKinnon Basketball Association Child Safe Policy. (2017). Retrieved from: https: / / websites.sportstg.com/assoc page.coi?c $=0-4059-0-0-0 \&$ sID $=85773$.

Mitchelstown Tennis Club Child Protection Policy. (2018).Retrieved from: https://mitchelstowntennisclub.com/wp-content/uploads/2018/05/Child-ProtectionPolicy-Updated-15-05-2018.pdf.

Mountjoy, M., Brackenridge, C. Arrington, M et al (2016) International Olympic Committee consensus statement: harassment and abuse (non-accidental violence) in sport. British Journal of Sports Medicine, 50, 1019-1029.

National Programme On The Elimination Of Child Labour Primary Education and Training Law Act No.222, Ministry of Labour and Social Security - Directorate General of Labour. (2017). Available

from: https://www.ailevecalisma.gov.tr/media/1321/cocukisciligimucadele 20172023 en.pdf.

Oktug Zengin, M.(2013). Reflection of regulations about alcohol advertisings in media in Turkey. Electronic Journal of Social Sciences, 12(43), 287-305.

Palmer-Felgate, S., Brackenridge, C., Rhind, D., \& Hills L. Child (2013). Child Exploitation and the FIFA world cup: a review of risks and protective interventions, Brunel University London. Available from: https://bura.brunel.ac.uk/bitstream/2438/10635/1/FullText.pdf.

Parasız, Ö. Şahin, M.Y., \& Çelik, A. (2015). Child protection program implementations in sport management. International Journal of Science Culture and Sport, 3, 641-653.

Rio 2016 Village Policies. (2016). Revieved from: https://www.olympic.org/athlete365/rio2016/village-policies/

Rugby Football Union Safeguarding Policy Guidance \& Procedures. (2013). Retrieved from:https://www.englandrugby.com/dxdam/8a/8a4d35ee-0a0a-458d-8bcc20dba6ff3065/safeguardingpolicybooklet.pdf. 
Uğurlu, A., \& Şahin, M. Y. (2020). A general assessment on alcohol use and smoking within the framework of child protection in sport programme. Journal of Human Sciences, 17(4), 986-998. doi:10.14687/jhs.v17i4.6068

Safeguarding Athletes from Harassment and Abuse in Sport IOC Toolkit for IFs and NOCs. (2010). Retrieved from: https://d2g8uwgn11fzhj.cloudfront.net/wpcontent/uploads/2017/10/18105952/IOC_Safeguarding_Toolkit_ENG_Screen_Full1.p df

Salim, M.(2011). From past to today child protection policies in Turkey and social services and child protection agency, Unpublished Master dissertation, Süleyman Demirel University Institute of Social Sciences, Isparta.

Savaşçı, B.(2012). Çocukların Cinsel İstismarı Suçu, Legal Yayınları, İstanbul.

Sport New Zealand Safe Sport For Children. (2017). Retireved from: https://sportnz.org.nz/managing-sport/search-for-a-resource/guides/safe-sport-forchildren

Supporting Fundamental Rights Reforms in Turkey. (2017). Retrieved from: https://ec.europa.eu/neighbourhood-enlargement/sites/near/files/adfr.pdf.

Turkish Badminton Federation National Team Duties and Responsibilities Directive. (2016). Retrieved from: https://www.badminton.gov.tr/son-haberler/1228-badminton-millitakimlar-gorev-ve-sorumluluklari-yonergesi.html.

Turkish Tennis Federation, Criteria for National Team Trainers. (2010). Retrieved from: https://www.ttf.org.tr/idari-duyurular/milli-takim-antrenorler-belirleme-kriterleri

UNICEF (2004). Sport, Recreation and Play. Geneva. Retrieved from: https://www.unicef.org/publications/index 23560.html.

UNICEF (2010). The Children Left Behind: A League Table of Inequality in Child Well-Being in the World's Rich Countries. Innocenti Report Card 9, United Nations Children's Fund (UNICEF) (Italy), Innocenti Research Centre. Retrieved from: https://www.unicefirc.org/publications/619-the-children-left-behind-a-league-table-of-inequality-in-childwell-being-in-the.html.

United States Olympic Committee Safe Sport Audit Report. (2017). Available from: https://www.teamusa.org/Team-USA-Athlete-Services/Safe-Sport/Safe-Sport-AuditReports.

Van de Mortel, Thea F. Faking it: social desirability response bias in self-report research source. Australian Journal of Advanced Nursing. 2008; 25:40-48.

World Health Organization Regional Office for Europe (2006). Framework for Alcohol Policy. Retrieved http://www.euro.who.int/_data/assets/pdf_file/0007/79396/E88335.pdf. [last accessed 20 May 2018].

Widom, C. S., \& Hiller-Sturmhöfel, S. (2011). Alcohol abuse as a risk factor for and consequence of child abuse. Alcohol Research \& Health, 25: 52-57.

World Rugby Union Child Safeguarding Policy. (2013). Retrieved from: http://www.rlif.com/ignite docs/RLIF\%20Safeguarding\%20Policy.pdf.

XC Bragg Creek Ski and Bike Society (XCBC) Athlete. (2018). Retrieved from: https://www.xcbraggcreek.ca/code-of-conduct/.

Yetim, A. (2011). Sosyoloji ve Spor, Berikan Yayınevi, Inc; 1st edition, Ankara. 